Sylwia Kaczmarek WL

\title{
Chryzostomowe Homilie na Księgę Rodzaju
}

„«A czy i nas - powiada - dotyczy opowiadanie o stworzeniu?». Właśnie nas dotyczy, umiłowany. Jeśli bowiem «poprzez wielkość i piękno stworzeń odpowiednio kontempluje się Twórcę» ${ }^{1}$, w takim razie: w jak wielkim stopniu poświęcimy czas pięknu i wielkości stworzeń, w tak wielkim zostaniemy poprowadzeni do Stwórcy.

Jest wielkim dobrem wiedzieć: czym jest stworzenie, czym zaś Stwórca; czym dzieło, czym Wykonawca. Jeśli wrogowie prawdy umieliby dokładnie oddzielać jedno od drugiego, nie pomieszaliby wszystkiego, przestawiając to, co jest na dole, z tym, co jest na górze: nie w tym sensie, iżby gwiazdy i niebo ściągnęli na dół, a ziemię wynieśli do góry, lecz w tym, że Króla niebios sprowadzili z tronu królewskiego i postawili razem ze stworzeniem, zaś stworzeniu przyznali pierwsze miejsce, należne bóstwu... Niebo jest piękne, abyś oddał pokłon Temu, kto je stworzył; słońce jest świetliste, abyś był pełen uszanowania dla jego Wykonawcy; jeśli zaś chcesz pozostawać w podziwie dla stworzenia i zatrzymać się na pięknie dzieł: światło stało ci się mrokiem² ${ }^{2}$ a raczej posłużyłeś się nim, by wejść w mrok.

Czy już pojmujesz, jakim dobrem jest rozumienie wypowiedzi na temat stworzenia?"3.

Powyższymi słowami antiocheński prezbiter w 386 roku - z kilkumiesięczną zaledwie praktyką głoszenia homiliii ${ }^{4}$ - przekonuje swe audytorium o sensie zajmowania się początkiem Księgi Rodzaju, która w drugiej połowie czwartego wieku tak na Wschodzie, jak na Zachodzie odczytywana była

${ }^{1} \operatorname{Mdr} 13,5$.

${ }^{2}$ Por. Hi 22, 11; Iz 59, 9 (za LXX); Mt 6, 23.

${ }^{3}$ Homilia I: Rdz 1, 1n, 1, [w:] Jan Chryzostom, Homilie na Księge Rodzaju (seria pierwsza: $R d z$ 1-3), wprow., przekł. i oprac. S. Kaczmarek, Kraków 2008, s. $52-53$ (Źródła Myśli Teologicznej, 45).

${ }^{4}$ Omawiane homilie nie są jednak debiutem Jana Chryzostoma. Wcześniej napisał on szereg pism dydaktycznych - por. Johannes Quasten, Patrologia, t. 2, tł. N. Beghin, Casale 1983, s. 466nn; J. N. D. Kelly, Złote usta. Jan Chryzostom - asceta, kaznodzieja, biskup, tł. K. Krakowczyk, Bydgoszcz 2001, s. 5nn. 
w czasie wielkiego postu ${ }^{5}$. Tym razem Jan Chryzostom, bo o nim mowa, poświęca księdze Genesis zaledwie kilka homilii ${ }^{6}$, podczas gdy po dwóch latach powróci do Księgi Rodzaju, by w sześćdziesięciu siedmiu homiliach w sposób systematyczny omówić jej kolejne rozdziały

Już liczba homilii z pierwszego cyklu na temat Księgi Rodzaju -w porównaniu z cyklem dłuższym - wskazuje, że Chryzostom musiał dokonać selekcji materiału. W jakim kluczu to uczynił? Wybrał kilka kwestii (gr. zetemata) ${ }^{8}$ związanych tematycznie z pierwszymi trzema rozdziałami Księgi Rodzaju i te kwestie dokładnie opracował. Roztacza przed swoimi wiernymi w czasie wielkiego postu tematy związane z powstaniem człowieka, zjego miejscem pośród stworzeń, utraconym poprzez grzech, jednak możliwym do odzyskania.

\section{Układ hierarchiczny bytów}

Słowa zacytowane na początku dobrze ujmują główną myśl homilii, a zarazem ich tło, a mianowicie odsłanianie właściwego porządku wszechświata, w którym każdy byt ma swoje miejsce. Chryzostom przekonuje, że odczytanie tego porządku jest ważne, ponieważ fałszywe spojrzenie na rzeczywistość i czyny wynikające z zapomnienia o właściwym sobie miejscu sprawiają, że człowiek zostaje pozbawiony tego, co już uzyskał, i tego, co jest dla niego przeznaczone, a - jak przekonuje homileta - nie są to rzeczy małe.

${ }^{5}$ Zarówno Bazyli Wielki, jak i Ambroży głoszą homilie objaśniające Heksaemeron właśnie w czasie Wielkiego Postu - por. Y. M. J. Congar, Le thème de Dieu créateur et les explications de l'Hexaéméron dans la tradition chrétienne, [w:] L’homme devant Dieu. Mélanges H. de Lubac I, Paris 1963, s. 193nn.

${ }^{6}$ Wspominam tu o kilku homiliach, ponieważ nie wiemy dokładnie, ile Chryzostom ich wygłosił. W najnowszym wydaniu krytycznym w serii Sources Chrétiennes znajdujemy osiem homilii, zaś wydanie Migne’a dołączało do nich homilię dziewiątą później przyporządkowaną do innego cyklu. Z zawartych w homiliach odwołaniach można wnioskować o zaginięciu przynajmniej jednej homilii - por. L. Brottier, Histoire du Texte, [w:] Jean Chryzostome, Sermons sur la Genèse, Paris 1998, s. 113n (Sources Chrétiennes, 433). J. N. D. Kelly uważa, że homilii było „o wiele więcej” (J. N. D. Kelly, Złote usta ..., dz. cyt., s. 68), co jednak naszym zdaniem nie musi być racją. Wprawdzie wielki post trwa czterdzieści dni i wydawałoby się uzasadnionym kontynuowanie homilii na temat wybranej księgi, jednak warto zauważyć, że zarówno św. Bazyli, jak i później św. Ambroży potraktowali temat kolejnych dni stworzenia w cyklu dziewięciu homilii (por. B. Altaner, A. Stuiber, Patrologia. Życie, pisma i nauka Ojców Kościoła, tł. P. Pachciarek, Warszawa 1990, s. 398 i 504), a zatem nie poświęcili Księdze Rodzaju całego wielkiego postu.

${ }^{7}$ Por. J. N. D. Kelly, Złote usta ..., dz. cyt., 99n.

${ }^{8}$ Por. Homilia II: Rdz 1, 26n, 1, [w:] Jan Chryzostom, Homilie..., dz. cyt., s. 62, gdzie pada ten termin. 
Jak wynika z cytowanego fragmentu, w rozpoznawaniu prawdziwego porządku rzeczy człowiek napotyka dwa zagrożenia. Po pierwsze, może przeoczyć piękno stworzeń i zapomnieć o wdzięczności należnej za nie Bogu; po drugie natomiast, może tak się nimi zachwycić, że im samym odda cześć należną Bogu. O niewłaściwości takiej postawy świadczy już fakt, że w jej konsekwencji podziwiane przez człowieka światło słońca wprowadza w jego życie mrok $^{9}$.

Chryzostom nie poprzestaje jednak na kosmologii. W porządek bytów w poszczególnych homiliach wpisuje kolejne stworzenia, ukazując człowieka jako ich króla. Tak jak pozytywnie wyrażał się o ziemi i niebie ${ }^{10}$, tak z jeszcze większym zachwytem pisze o człowieku. Gdy odkrywa treść zawartą w słowie: „Uczyńmy”, poprzez które Bóg, inaczej niż w przypadku wcześniejszych stworzeń, zwraca się do kogoś równego godnością (później określonego jako Przedziwny Doradca, Książę pokoju ${ }^{11}$ ), Chryzostom z nieukrywanym wzruszeniem dotyka wielkiej tajemnicy, która łączy początek z wiecznością, i mówi: „Kimże jest ten, kto ma być stworzony, że tak wielkiej czci doznaje? To jest człowiek: wielka i godna podziwu istota, cenniejsza dla Boga niż cała reszta stworzenia, ze względu na którą istnieje niebo i ziemia, i morze, i każdy element stworzenia; człowiek, którego zbawienia Bóg tak pragnął, że dla niego nie oszczędził ${ }^{12}$ nawet Jednorodzonego. Gdyż Bóg nie ustał, czyniąc wszystko i podejmując starania, dopóki nie wyniósł go i nie posadził po swojej prawicy. Paweł głosi: «Wskrzesił nas razem i razem posadził» po swej prawicy «na wyżynach niebieskich w Chrystusie Jezusie» (Ef 2, 6)"13.

Chryzostom nie przepuszcza żadnej okazji, by podkreślać wielką godność człowieka. Ta wielkość wynika z zamiarów Bożych względem człowieka. Godność tę unaocznia wezwanie: „Uczyńmy”: fakt, że przy stworzeniu człowieka Bóg zwraca się do Jednorodzonego Syna, choć wcześniej wszystko powstało na słowa: „Niech się stanie” (Rdz 1, 3) $)^{14}$; znakiem uprzywilejowania człowieka jest też przyznanie mu panowania nad zwierzętami, zanim jeszcze został stworzony - Chryzostom podkreśla tę uprzedniość, wnioskując na jej podstawie, iż człowiek niczym sobie nie zasłużył na swą wyjątkową pozycję ${ }^{15}$. Niezwykłą godność człowieka ukazuje

\footnotetext{
${ }^{9}$ Por. Homilia I: Rdz 1, 1n, 1, [w:] Jan Chryzostom, Homilie..., dz. cyt., s. 53.

${ }^{10}$ Por. Homilia II: Rdz 1, 26n, 3, [w:] Jan Chryzostom, Homilie..., dz. cyt., s. 58.

${ }^{11}$ Por. Iz 9, 5.

12 Por. Rz 8, 32.

${ }^{13}$ Homilia II: Rdz 1, 26n, 1, [w:] Jan Chryzostom, Homilie ..., dz. cyt., s. 64.

${ }^{14}$ Por. Homilia II: Rdz 1, 26n, 1, [w:] Jan Chryzostom, Homilie..., dz. cyt., s. 63n.

${ }^{15}$ Por. Homilia II: Rdz 1, 26n, 1, [w:] Jan Chryzostom, Homilie..., dz. cyt., s. 64.
} 
także fakt, że tylko Adam i Ewa zostali stworzeni na obraz i na podobieństwo Boga, przy czym obraz dotyczy tu władzy (arche) przejawiającej się w tym, że człowiek nie ma nad sobą nikogo ${ }^{16}$, natomiast podobieństwo wyraża się w uległości i cichości ${ }^{17}$.

Tak jak ziemia została zatem zaopatrzona we wszystko przez Boga, aby służyć człowiekowi, tak człowiek wszystko otrzymał, bez swoich zasług, aby przebywać ze swym Stwórcą, aby się z Nim komunikować (tu Chryzostom posługuje się słowami z rodziny homilia $)^{18}$. Podkreślanie przez Złotoustego godności człowieka wiąże się zatem z pokazywaniem wielkości Boga i Jego miłosierdzia. Bóg, który nie podlega prawom natury i nie da się pojąć ludzkim rozumem, swoją wielkością buduje autorytet człowieka.

\section{Zachwianie panującego porządku przez grzech}

Stan komunikowania się z Bogiem trwał w raju, jednak, jak pisze Chryzostom, przez grzech natura ludzka sama skazała się na wygnanie ${ }^{19}$. Zachwiany został porządek wszechświata, w którym Panem i wspólnym królem wszystkich jest Bóg. Wobec Niego wszyscy inni są sługami ${ }^{20}$. Ludzie pomiędzy sobą są współsługami ${ }^{21}$, a wobec zwierząt są panami ${ }^{22}$. I znowu Bóg jako pierwszy wychodzi ku człowiekowi. Gdy ludzie byli na wygnaniu, Bóg ułożył Pismo - nazywane też „listem” i ,apologią” - i dostarczył je ludziom przez Mojżesza, aby odnowić dawną przyjaźń (philia) ${ }^{23}$. W tym liście Bóg daje wytłumaczenie stanu, w jakim ludzie znaleźli się po grzechu, a także przyodziewa ich - jak pisze Chryzostom, najprawdopodobniej nawiązując do sytuacji z raju, gdzie Bóg dał nagim ludziom odzienie - w środki obronne, aby mogli uniknąć kary w czasie zdawania rachunku z życia ${ }^{24}$.

Chryzostom, jak wspomnieliśmy wyżej, nazywa Pismo „apologią”. W Piśmie Bóg odpowiada bowiem człowiekowi na najbardziej egzystencjalne pytania, na jego żale, a z drugiej strony daje wskazania, jak żyć, aby ujść kary za popełnione grzechy ${ }^{25}$. Chryzostom pomaga swym słuchaczom dostrzec bezzasadność ich żalów kierowanych do Pana Boga z powodu

${ }^{16}$ Por. Homilia II: Rdz 1, 26n, 2, [w:] Jan Chryzostom, Homilie..., dz. cyt., s. 66.

${ }^{17}$ Por. Homilia III: Rdz 1, 26n, 1, [w:] Jan Chryzostom, Homilie..., dz. cyt., s. 69n.

${ }^{18}$ Por. Homilia I: Rdz 1, 1n, 2, [w:] Jan Chryzostom, Homilie..., dz. cyt., s. 54.

${ }^{19}$ Por. Homilia I: Rdz 1, 1n, 2, [w:] Jan Chryzostom, Homilie..., dz. cyt., s. 54.

${ }^{20}$ Por. Homilia III: Rdz 1, 26n, 2, [w:] Jan Chryzostom, Homilie..., dz. cyt., s. 71.

${ }^{21}$ Por. Homilia I: Rdz 1, 26n, 3, [w:] Jan Chryzostom, Homilie..., dz. cyt., s. 58.

${ }^{22}$ Por. Homilia III: Rdz 1, 26n, 2, [w:] Jan Chryzostom, Homilie..., dz. cyt., s. 70-72.

${ }^{23}$ Por. Homilia I: Rdz 1, 1n, 2, [w:] Jan Chryzostom, Homilie..., dz. cyt., s. 54.

${ }^{24}$ Por. Homilia I: Rdz 1, 1n, 1, [w:] Jan Chryzostom, Homilie..., dz. cyt., s. 54.

${ }^{25}$ Por. Homilia I: $R d z$ 1, 1n, 1, [w:] Jan Chryzostom, Homilie..., dz. cyt., s. 54. 
uciążliwości życia, a także z powodu niesprawiedliwości, jakiej się niektórzy dopatrywali w dziedziczeniu win po pierwszych ludziach. Wykazuje, że pierwszy grzech został popełniony w sposób świadomy, bo pierwsi ludzie umieli rozróżniać dobro i zło ${ }^{26}$. Ewa dała się zwieść kłamstwu węża i okazała nieposłuszeństwo Panu Bogu, dopuszczając się przekroczenia jego nakazu. Dlatego utraciła obraz Boży i została podporządkowana mężowi, a po niej wszystkie niewiasty ${ }^{27}$. Z kolei Cham przez opowiedzenie braciom o nagości ojca zasłużył na to, by zgodnie ze słowami ojca stać się sługą swych braci - co zapoczątkowało stan niewolnictwa ${ }^{28}$. Także prawo i sprawujący władzę pojawili się w konsekwencji tego, że ludzie czynili sobie nawzajem krzywdę ${ }^{29}$.

Antiocheńczyk pokazuje jednak, że jeden grzech nie przesądził o wszystkim. Po pierwsze, każdy grzech pociąga za sobą niewolę i śmierć. Przewiny pierwszych ludzi zostają potwierdzone przewinami kolejnych pokoleń. Ludzie nie są zatem zdeterminowani przez swych poprzedników ${ }^{30}$. Według Chryzostoma każdy może rozluźnić stan niewoli poprzez cnotę, czego przykładem są przywołane przez niego postaci ze Starego i Nowego Testamentu (np. Daniel). Ludzie ci „otrzymali prawo, a nie upadli, lecz spełnili więcej, niż im nakazano"31. Każdy bowiem sam decyduje o swoich wyborach, a główną przyczyną upadku jest gnuśność (rathymia) 32 przywara, darzona przez Chryzostoma największą niechęcią. To ona bowiem skłoniła człowieka do zlekceważenia miłującego Ojca, Boga ${ }^{33}$.

Zestawmy w tym miejscu konsekwencje grzechu. Jak zaznaczyliśmy wcześniej, grzech narusza porządek w systemie zależności. Gdy człowiek okazuje nieposłuszeństwo swemu władcy, sam zaczyna się lękać niżej od siebie postawionych bytów, a konkretnie zwierząt ${ }^{34}$. Przez grzech traci też władzę, udział w obrazie. I tak nie są mu już posłuszne dzikie zwierzęta, żona jest poddana mężowi, niewolnicy panom, większość społeczeństwa sprawującym władzę i prawom mogącym nawet odebrać człowiekowi życie. Nieuporządkowanie w relacjach pomiędzy ludźmi polega również na tym,

${ }^{26}$ Por. Homilia VI: Rdz 2-3, 1, 2, [w:] Jan Chryzostom, Homilie..., dz. cyt., s. 92-95.

${ }^{27}$ Por. Homilia IV: $R d z$ 3, 16, 1, 2 i Homilia V: Rdz 3, 16, 1, [w:] Jan Chryzostom, Homilie..., dz. cyt., s. 82-84.

${ }^{28}$ Por. Homilia IV: Rdz 3, 16, 2, [w:] Jan Chryzostom, Homilie..., dz. cyt., s. 76n.

${ }^{29}$ Por. Homilia IV: Rdz 3, 16, 2, [w:] Jan Chryzostom, Homilie..., dz. cyt., s. 77n.

${ }^{30}$ Por. Homilia V: Rdz 3, 16, 1, [w:] Jan Chryzostom, Homilie..., dz. cyt., s. 81-84.

${ }^{31}$ Homilia VIII: Rdz 2, 16-17, 2, [w:] Jan Chryzostom, Homilie ..., dz. cyt., s. 112.

${ }^{32}$ Por. Homilia VIII: Rdz 2, 16-17, 2, [w:] Jan Chryzostom, Homilie..., dz. cyt., s. 112.

${ }^{33}$ Por. Homilia IV: Rdz 3, 16, 2, [w:] Jan Chryzostom, Homilie..., dz. cyt., s. 78.

${ }^{34}$ Por. Homilia III: Rdz 1, 26n, 2, [w:] Jan Chryzostom, Homilie..., dz. cyt., s. 70n. 
że niektórzy próbują budować relacje w oderwaniu od podstawowej relacji do Boga. Możemy to wyczytać na przykładzie ostrej krytyki wymierzonej przeciw heretykom. Chryzostom ostrzega przed nimi swoich wiernych, obnażając obłudę ich postawy. Niemożliwe jest bowiem troszczyć się o współsługę, o poprawność jego myślenia, a jednocześnie jak wściekły pies atakować wspólnego Pana ${ }^{35}$. Możemy zatem uznać, że relacje pomiędzy ludźmi bazują na wertykalnej relacji do Pana Boga, a gdy ta zostanie zakłócona, wszystkie relacje ulegają wypaczeniu.

\section{Miłosierny Bóg podnosi człowieka ku coraz wyższej godności}

Chryzostom dowodzi, że człowiek sam odpowiada za swój grzech i jego konsekwencje. Co charakterystyczne, nie zatrzymuje się on jednak zbyt długo na złu. Od razu stara się otwierać oczy wiernych na nadzieję. Powtarzając, że Bóg nie ukarał człowieka, antiocheńczyk wskazuje, że stało się wprost przeciwnie. Bóg nie tylko nie odwrócił się od człowieka, ale zorganizował konsekwencje jego grzechu tak, aby człowiek porzucił swą gnuśność i powrócił na swoje miejsce ${ }^{36}$. Podporządkowanie ludziom i prawom oraz lęk przed zwierzętami powinny w nim obudzić pragnienie wydobycia się z tego stanu. O tyle ponoszenie konsekwencji grzechu jest środkiem pedagogicznym ${ }^{37}$. Ponadto Bóg hojnie nagradza tych, którzy poprzez cnotę zachowują wolność. W końcu, jak pisze Chryzostom, „choćby diabeł uknuł niezliczone podstępy przeciw rodzajowi ludzkiemu, nic mu to nie da, ponieważ Bóg do coraz większej godności wciąż nas podnosi. Utraciłeś wprawdzie raj, ale Bóg otwarł ci niebo. Zostałeś skazany na tymczasowy trud, a uczczony zostałeś życiem wiecznym. Rozkazał ziemi rodzić ciernie i osty ${ }^{38}$, ale dusza wydała ci owoc Ducha (Hbr 6, 4-8)"39.

Wynoszenie człowieka coraz wyżej ${ }^{40}$ dokonuje się zatem przez zniżanie się Boga ku człowiekowi ${ }^{41}$, przez akty Bożego miłosierdzia: komunikowa-

${ }^{35}$ Por. Homilia I: Rdz 1, 1n, 3, [w:] Jan Chryzostom, Homilie..., dz. cyt., s. 58.

${ }^{36}$ Por. Homilia IV: Rdz 3, 16n, 2, [w:] Jan Chryzostom, Homilie..., dz. cyt., s. 78.

${ }^{37}$ Por. Homilia IV: Rdz 3, 16n, 2, [w:] Jan Chryzostom, Homilie..., dz. cyt., s. 78.

${ }^{38}$ Por. Rdz 3, 18; Mt 7, 16; Hbr 6, 48.

${ }^{39}$ Homilia VII: Rdz 2-3, 5, [w:] Jan Chryzostom, Homilie ..., dz. cyt., s. $105 n$.

${ }^{40}$ Czasownik oddający w języku greckim podnoszenie człowieka należy do tej samej rodziny, co znany termin anagoge - por. Homilia VII: Rdz 2-3, 5, [w:] Jan Chryzostom, Homilie..., dz. cyt., s. 105.

${ }^{41}$ W homiliach Chryzostoma znajdziemy termin synkatabasis oznaczający zniżanie się Boga i Jego dostosowywanie się do możliwości poznawczych człowieka - por. Homilia II: Rdz 1, 26n, 2, [w:] Jan Chryzostom, Homilie..., dz. cyt., s. 65. 
nie się z człowiekiem, najpierw w raju, później przez Pismo ${ }^{42}$, najmocniej w swoim Synu, przez nowe zrodzenie z wody i z Ducha ${ }^{43}$.

Chryzostom chętnie zestawia Adama i Jezusa, podobnie jak w duchu typologii zestawia drzewo poznania dobra i zła i drzewo krzyża. Podkreśla on za św. Pawłem, w świetle którego listów odczytuje Księgę Rodzaju, że dobra przyniesione przez Jezusa znacznie przekraczają te, których pozbawił ludzkość wygnany z raju Adam. Chrystus zgładził nie tylko grzech Adama. On jest Barankiem, który gładzi grzech świata. Nie prowadzi On też człowieka na powrót do raju, lecz do samego królestwa niebieskiego, do nieba ${ }^{44}$.

Dynamika prowadzenia człowieka coraz wyżej realizuje się mocą ofiary Chrystusa, jednak przynosi ona owoce tylko w życiu tych, którzy dają się prowadzić. Chryzostom przytacza rady, jakie Pismo daje ludziom już w Starym Testamencie. Przypomina za Izajaszem o konieczności porzucenia zła, oczyszczenia się, czynienia dobra, wyznawania swych win, aby wyprzedzić zarzuty ze strony oskarżyciela ${ }^{45}$ natury ludzkiej, kłamcy, diabła. W kolejnych podejściach Chryzostom podejmuje temat realizacji Bożej woli i takiego postępowania, które jest nagrodzone życiem wiecznym, dobrami, których oko nie widziało ani ucho nie słyszało (por. 1 Kor 2, 9) ${ }^{46}$.

\section{Warunek przebywania z Chrystusem}

Jak wejść w posiadanie niepojętych dóbr? Po pierwsze warto zaznaczyć, czym dla Chryzostoma są owe dobra. Nie chodzi mu o jakąś abstrakcyjną nagrodę. Wartość tej nagrody wyłania się przez skojarzenie jej z Osobami Boskimi. Nieposłuszeństwo Bogu Chryzostom pozwala zobaczyć na tle nieposłuszeństwa wobec władcy i nieposłuszeństwa Ojcu. Podobnie tym, co najlepszego może spotkać człowieka tutaj na ziemi, jest bycie blisko Chrystusa. Wyjątkowość tej relacji wybrzmiewa z pośredniego zestawienia związku małżeńskiego i oblubieńczego związku pomiędzy Chrystusem a Kościołem ${ }^{47}$. Człowiek staje się godny bliskości Chrystusa, gdy naśladuje Jego uległość i cichość w realizowaniu woli Boga i w przestawaniu z ludźmi.

\footnotetext{
${ }^{42}$ Por. Homilia I: Rdz 1, In, 2, [w:] Jan Chryzostom, Homilie..., dz. cyt., s. 54.

${ }^{43}$ Por. Homilia VII: Rdz 2-3, 5, [w:] Jan Chryzostom, Homilie..., dz. cyt., s. 106.

${ }^{44}$ Por. Homilia VII: Rdz 2-3, 3-5, [w:] Jan Chryzostom, Homilie..., dz. cyt., s. 102nn.

${ }^{45}$ Por. Homilia I: Rdz 1, 1n, 1, [w:] Jan Chryzostom, Homilie..., dz. cyt., s. 54.

${ }^{46}$ Por. Homilia VII: Rdz 2-3, 5, [w:] Jan Chryzostom, Homilie..., dz. cyt., s. 105n.

${ }^{47}$ Por. Homilia IV: Rdz 3, 16, 2, [w:] Jan Chryzostom, Homilie..., dz. cyt., s. 76. Chryzostom nie porównuje wprost tych dwóch związków, jednak przy odczytywaniu wersetu Rdz 3, 16 traktującego o poddaniu niewiasty mężczyźnie sięga po werset z Listu do Efezjan (Ef 5, 25), gdzie związek pomiędzy mężem a żoną zestawiony jest z relacją pomiędzy Chrystusem
} i Kościołem. 
Gdy dostrzega Chrystusa ukrytego dla oczu świata hańbą krzyża, ale też nędznym odzieniem ubogich ${ }^{48}$. Ten, kto umie - jak łotr na krzyżu - patrzeć oczami wiary $^{49}$ i kto - jak uboga wdowa - wielkodusznie odda wszystko, ten zasłuży na niebo ${ }^{50}$. Nikt nie powinien wątpić w możność dostąpienia odpuszczenia win. Chryzostom zauważa, że Pan Bóg celowo na oczach wszystkich wprowadza łotra do raju, gdyż pragnie, ,aby nikt z ludzi, którzy mieli się później narodzić - widząc, jak człowiek obciążony niezliczonymi niegodziwościami przechadza się po komnatach królewskich - nie stracił nadziei na wejście tam i żeby nie zwątpił we własne zbawienie" ${ }^{51}$.

Dlatego może w homiliach Chryzostoma wyczuwalna jest głęboka radość. Od pierwszej homilii uświadamia on wiernym, że Bóg już przy stwarzaniu świata czynił wszystko z myślą o człowieku i jego zbawieniu ${ }^{52}$. On jest miłosierny - philanthropos, miłuje człowieka i czyni wszystko, aby człowiek zajął miejsce po Bożej prawicy ${ }^{53}$. On towarzyszy człowiekowi - jest obecny w zgromadzeniu wiernych ${ }^{54}$, poprzez pasterzy troszczy się o swój lud ${ }^{55}$, daje się poznać i zasiada przy stole ludzi, gdy ci żyją zgodnie z Pismem, gdy naśladują Boga w Jego umiłowaniu człowieka ${ }^{56}$. Czy przebywanie pośród ojców i braci, którzy idą tą samą pewną drogą, i pośród świętych, którzy tą drogą już przeszli, może nie pobudzać do radości?

Tylko ci nie zdołają prawdziwie rozradować się Bożym przebaczeniem i obdarowaniem, którzy nie starają się, z gorliwością, o powierzony sobie talent. Bóg będzie bowiem na sądzie rozliczał człowieka z tego, czy przyjął talent Pisma, czy ochronił jego przesłanie prawymi dogmatami, przez wiarę i wierność tradycji ojców, czy ten talent podwoił przez dzielenie się tym, czego się dowiedział w Kościele. A w końcu, czy te nauki są obecne w jego życiu ${ }^{57}$. W jednej z końcowych homilii Chryzostom ostrzega: „Czas postu, tyle słuchania i nauczania zbawczych pouczeń, nieustanne modlitwy, codzienne zgromadzenia - i co po tak wielkim staraniu, gdy stąd wracamy? Widząc szeregi biedaków, stojących rzędem po obu naszych stronach, patrzymy na nich jak na kolumny, a nie jak na ludzkie ciała i przebiegamy obok bez okazania

\footnotetext{
${ }^{48}$ Por. Homilia VIII: Rdz 2, 16-17, 2, [w:] Jan Chryzostom, Homilie..., dz. cyt., s. 113.

${ }^{49}$ Por. Homilia VII: Rdz 1, 1n, 4, [w:] Jan Chryzostom, Homilie..., dz. cyt., s. 104.

${ }^{50}$ Por. Homilia I: Rdz 1, 1n, 4, [w:] Jan Chryzostom, Homilie..., dz. cyt., s. 60.

${ }^{51}$ Homilia VII: Rdz 2-3, 4, [w:] Jan Chryzostom, Homilie..., dz. cyt., s. 103.

${ }^{52}$ Por. Homilia I: Rdz 1, 1n, 3, [w:] Jan Chryzostom, Homilie..., dz. cyt., s. 58.

${ }^{53}$ Por. Homilia II: Rdz 1, 26n, 1, [w:] Jan Chryzostom, Homilie..., dz. cyt., s. 64.

${ }^{54}$ Por. Homilia VI: Rdz 2-3, 1, [w:] Jan Chryzostom, Homilie..., dz. cyt., s. 92.

${ }^{55}$ Por. Homilia VIII: Rdz 2, 16-17, 1, [w:] Jan Chryzostom, Homilie..., dz. cyt., s. 108.

${ }^{56}$ Por. Homilia VIII: Rdz 2, 16-17, 2, [w:] Jan Chryzostom, Homilie..., dz. cyt., s. 113.

${ }^{57}$ Por. Homilia II: Rdz 1, 26n, 2, [w:] Jan Chryzostom, Homilie..., dz. cyt., s. 67.
} 
zmiłowania... i po takim akcie braku miłosierdzia śmiemy wyciągać ręce do nieba i rozmawiać z Bogiem o miłosierdziu, i prosić o wybaczenie naszych grzechów; i nie boimy się, że po takiej modlitwie, poprzedzonej tak wielkim okrucieństwem i brakiem miłosierdzia spadnie piorun?"58.

\section{Zakończenie}

Chryzostom jawi się w swoich homiliach jako człowiek gorliwie zabiegający o wzrost swoich słuchaczy. Różnymi sposobami stara się ich pouczyć, co czynić, aby nauka Pisma przeniknęła całe ich życie. Co więcej, przygotowuje ich do samodzielnej lektury, ucząc ich, jak dostrzegać rzeczywistość kryjącą się za słowem: jak nawet w lekturze Starego Testamentu nie stracić z oczu Chrystusa i jak przez wszystko się do Niego zbliżać. Korygując sposób myślenia swych słuchaczy i ukazując, jak bronić dogmatów w polemice z wrogami wiary, jak nie ufać miłym słowom tych, którzy są niczym „wściekłe psy” wobec „wspólnego Pana”, Chryzostom zaznacza, że to nie wszystko. Dogmaty i wiara, a nawet pouczanie muszą się przekładać na życie. Dopiero te wszystkie elementy składowe poparte pośrednictwem kapłanów i miłosierdziem Boga ${ }^{59}$ gromadzą człowiekowi prawdziwe dobra w niebie, dając mu nadzieję zbawienia, a już na ziemi przywracają mu jego godność.

Chryzostom ukazuje szereg osób, które wskazaną drogą podążyły. Przez swe życie i on sam w ten szereg się wpisuje. I pewnie dlatego właśnie homilie Antiocheńczyka do dziś mogą pomóc tym, którzy pragną wydobyć się z zamętu tak często panującego w relacjach z Bogiem, z ludźmi, ze stworzeniem i powrócić do harmonii, jaką Stwórca zapisał w świecie.

Złotousty, wyposażony w instrumentarium retoryczne, przez wszystko stara się odsłonić nowość Ducha, prowadzi ku Komuś innemu, kto jest nieskończenie bardziej interesujący, poruszający, kto pouczaniem podnosi. Tego Kogoś pomaga spotkać, świadom, że ostatni krok każdy musi wykonać sam.

Kraków

Sylwia Kaczmarek WL

\section{Słowa kluczowe}

Jan Chryzostom, apologia, stworzenie, porządek bytów, obraz Boży, grzech, miłosierdzie Boga, zbawienie, Homilie na Księgę Rodzaju

${ }^{58}$ Homilia V: Rdz 3, 16n, 3-4, [w:] Jan Chryzostom, Homilie..., dz. cyt., s. 88nn.

${ }^{59}$ Por. Homilia I: Rdz 1, 1n, 4, [w:] Jan Chryzostom, Homilie..., dz. cyt., s. 60n. 


\section{Summary}

\section{Chrysostom's Homilies on Genesis}

The series of the eight homilies on Genesis written by John Chrysostom include many clues to why the article was chosen. It is considered on the grounds that it is leitmotiv. It is the clue of the order of beings - settled at the moment of creation, spoiled by sin, looked to be restored by human effort and fully realized in Christ. This order, which consists on the different relations, is shown as the important point of interest in the examination of the others clues. We are referring to the dignity of the man created in God's image as well as similitude; the system of the dependencies between the beings; the significance of the sin of the people at the beginning and other sins; the idea in which God loves man; the salvation and the reward of the Kingdom of Heaven. This article tends also to show, how Chrysostom looks to help his followers during their meeting Christ, in the way of the studying the Scripture, of dogmas and of the life, which should be coherent to the Scripture.

\section{Keywords}

John Chrysostom, apology, creation, order of beings, image of God, sin, mercy of God, salvation, Homilies on Genesis 